\title{
Spelling Errors of Emirati Grade Six Male Students at Umm Al-Quwain Educational Zone /UAE.
}

\author{
Dr. Mohammed Hamid Al-Ta'ani \\ Emirates Canadian University College \\ dr.mattar1989@hotmail.com
}

< DOI: 10.26821/IJSRC.6.12.2018.61204 >

\begin{abstract}
This study aims to identify the spelling errors and examine the causes of misspelt words made by grade six male students at Umm Al-Quwain Educational Zonel UAE. The participants in the present were [30] male students.

The errors were identified, classified and statistically analyzed and interpretations were made. Next, the data were analyzed according to Cook's classification of spelling errors:omission, substitution, insertion and transposition. The results revealed that substitution errors ranked the highest percentage[83\%]. This is

followed by others in the following order: omission [56\%],insertion [56\%] and transposition [34\%].The researcher attributed these [4] types of errors to :- the incompatibility of pronunciation with the spelling in English; the lack of confusion between Arabic vowels and the English ones; mother tongue interference; ignorance of spelling rules and their exceptions; lack of morphological knowledge(i.e inflectional endings) and the learners' inattention or carelessness. Based on the findings, Pedagogical implications and recommendations were highlighted.
\end{abstract}

Key words: Spelling errors, grade six students, sources of spelling errors, types of errors.

\section{INTRODUCTION}

\section{Theoretical Background and Significance of the Study}

Among the four skills that are the goals of English as a second language (ESL) instruction- listening, speaking ,reading, writing -Writing is commonly last : last to be Dr. Mohammed Hamid Al-Ta'ani, Vol 6 Issue 12, pp 24-32, December 2018 taught in the sequence of skills and last to receive much emphasis and much attention : writing includes several subskills, one of which is spelling.

Spelling is very important for at least two reasons. First, a writer may not communicate well if she/he cannot spell; that is, a reader must be able to interpret the marks on the page as meaningful words and she/he cannot do this easily when words are misspelled. Second, contemporary American society considers misspelling is a serious social error, marking a person as, at least, "illiterate", if not outright "ignorant"(Connell, 1979, p. 202).

Spelling is an important part of learning to write; especially when one's writing is shared with others. The most effective way to teach spelling is to link it with reading and writing.

Spelling is the learner's ability to write a word correctly. Writing accurate spelling adds to the quality of overall writing texts. The study of learner's spelling errors provides an opportunity to understand and facilitate the learners' spelling difficulties. It will result in the improvement of learners' writing and may largely contribute to transforming learners into good writers. Spelling errors attribute to major errors writing English. The researcher reviewed the studies that focused on students' spelling errors, especially in United Arab Emirates (UAE) and found that a very few studies have been carried out with regard to the difficulties that Arab students have in spelling. Cook (1999) investigated the most common types of spelling errors in the written work of learners of English and he concluded that English spelling errors can be classified into four major categories first, the omission (leaving letters out). The second category is substitution (replacing letters with incorrect ones). The third category is transposition 


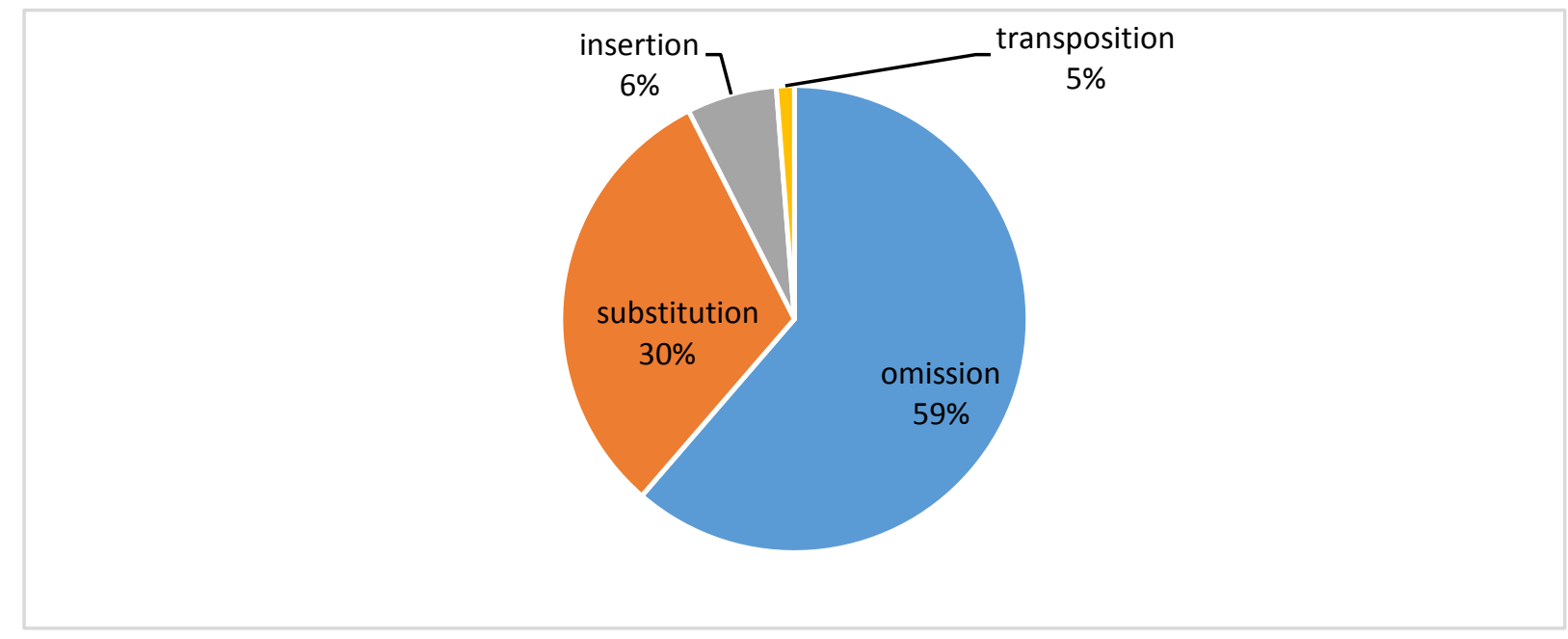

\section{Figure 1: types of spelling}

(Insertion 6\%, transposition 5\%, omission 59\%, and substitution 30\%). The researcher classified learners' spelling errors according to Cook's classification.

\section{Arab learners and English spelling.}

Arab learners of English make two particular kinds of errors, according to Al-Jarf (2008) first; inter lingual errors, which are caused by $\mathrm{L} 1$ interference. For example, Arab learners have a problem in distinguishing between $\{b\}$ and $\{\mathrm{p}\}$ because in Arabic there is one sound only for $/ \mathrm{b} /$. There is no /p/ sound. The second type of error Al-Jarf (2008) mentions is intra-lingual. This arises from a misunderstanding of the L2 and its structure

On the other hand, researchers like Smith (cited in Swan and Smith 2001) impute the spelling errors that Arab learners make to the difference between English and Arabic writing systems,

and also to the fact that Arabic spelling is closely related to its sound system

Emirati EFL learners also may have many difficulties with English vowels because English and Arabic have to different vowel systems. They have difficulty in hearing and producing /i/ as a different vowel from /e/ (Al-Hamush and Addulrahim 1979, p.114).

Moreover, Hasan (2000, p.3) states that English is not a phonetic language, i.e., it is not written as it is spoken it does not have closer phoneme-grapheme correspondence. Therefore, spelling difficulties are expected to rise for foreign learners learning English

as a foreign language, but also for native speakers.

Finally, the researcher developed an impression that Emirati EFL learners face many spelling problems when they need to write English. For example, the addition of some morphemes to many words involves other sounds and

spelling changes in patterns already unfamiliar to the learners.

Destroy + ive $=$ destructive
Satisfy + or $=$ satisfactory

(Al-Jubouri, 2006, p. 4)

\section{Statement of the Problem}

It has been noticed that most Emirati EFL learners who study English for about twelve years or more are unable to write sentences or a piece of writing without committing spelling errors. It is sufficient to ask EFL teachers and supervisors of English to look at compositions or pieces of writing to realize the widespread gravity of these spelling errors. Such a serious and crucial problem deserves, needless to say, a thorough investigation.

Spelling errors are representative of the sort of errors that proved to be recurrent and systematic in the sense that they are made by a larger number of the learners or are recurrent in the writing of a creative student. Furthermore, these errors persist from week to week and recur from one year to 
year with the same or new learners.

The need for continued spelling research to support old conclusions or give new insights in the entire area of the spelling was recommended by Share and Mulry (1963, p. 80).Further, Fitzgerald (1952, p.221) has indicated that an area which received little attention by researchers is that spelling errors and their persistence in writing .

Herman (1986, p. 254) declared that "poor spelling may be a serious handicap for many people to spell correctly and confidently. So, a determined effort of research is needed to overcome this handicap." Furthermore, he restressed the importance of correct spelling." He also indicated the importance of spelling research in avoiding learners many errors and enabling them to master the most productive skill of any language that is writing.

Generally speaking, spelling is considered as a marginal skill which receives the least attention. Thus, it becomes a chronic disease among our students once they get to advance stages of their study.

Considering the aforementioned suggestions and have personally observed the incidence errors in writing by English language learners, these errors should be taken seriously for the simple fact that they have been produced spontaneously in free writing which could be said to reflect truly the learners ' competence.Therefore, the problem of spelling seems an important need.

\section{Need for the study:}

There are many factors that stand behind writing on spelling errors in English for teaching purposes. Nasr (1963, p. 106) concentrates on the importance of correct spelling saying that ' ...... Correct spelling is just as important in writing as correct pronunciation in speaking.' This point is also discussed by Rivers (1968).

In addition to that, Cronnell (1979, pp202 - 214) indicates that as well as the social implications of irregular spelling, misspelling clearly reduces linguistic redundancy and thus increases the opportunities of misunderstanding in any written communication.

On the other hand, it is pointed out ( Fitzgerald , 1952 pp. 221 - 228 , Ramadan ,1986, p.6 and El - Hibir and Altaha 1993 ,p.41 and Smadi, 1994 ,pp.17-46 ) that there have been few studies conducted in the field of spelling by comparison with syntax, lexicon and pronunciation .Brown (1970, pp233- 236 ) also made a similar judgment that instructions of spelling in English as a foreign language had often overlooked in comparison of syntax and pronunciation. Thus, such a study is needed and recommended in an area where only few studies have been done out to detect the causes of spelling errors made by Arab learners learning
English as a foreign language

Moreover, the spelling errors that may be identified by such a study can provide curriculum planners and developers with useful information for constructing appropriate syllabuses and designing remedial courses. It can also provide some insights for the teaching of orthography in EFL Context (Al - Othman, 2003, p.8).

In turn, students may benefit from syllabuses and materials that are constructed in the light of known problematic areas, especially the students whom the study covers.

In the light of the aforementioned, the researcher finds that the need is urgent to investigate in an area which received very little attention by the researchers. It is the area of spelling errors and their persistence in written scripts.

\section{Objectives of the study}

The main goal of this study is to determine learners' spelling errors, and classify the errors created by grade six students at Othman Bin Affan Middle School into four categories. In this connection, the present study aims to achieve the following objectives.

1. What are the most common spelling errors that the Emirati grade six students commit in their writing?

2. In Which type do the most frequent errors occur?

3. What are the sources of spelling errors made by the students?

4. What the recommendations, suggestions and pedagogical implications to remedy these errors and help the students and teachers to overcome these difficulties?

\section{Literature Review}

The researcher has tried to be rational in reviewing the studies conducted in spelling errors. Some studies have been done in this area compared to syntax, lexicon and pronunciation. The researcher classified spelling errors studies into two parts:

1- Studies on Arab Learners.

2- Studies on foreign Learners.

\section{Studies on Arab Learners:}

Al-Jabri (2006) examined the spelling errors of [114] Omani grade five students in two rural schools. He collected his data from spelling tests on [10] words. He found that the most common errors were in omission and substitution, while transposition and insertion errors were less frequent.

Al- Jarf (2007) investigated spelling errors of [ 36] firstyear students majoring in English Language and translation 
in a university in Saudi Arabia. He found that important influences in English spelling errors were Arabic spelling system, students' mispronunciation, interference with other English words and unfamiliarity with American pronunciation. She recommended to conduct a study on these influences in understanding Arab students' difficulties of English spelling.

Al-zuoud and Kabilan(2013) studied spelling errors of [43] Jordanian students in their written compositions in a university. They found that [228] spelling errors occurred in [43] written papers. They categorized these spelling errors according to Cook's classification (1999). Their findings revealed that substitution and omission were the most frequent spelling errors.

Al-Oudat (2017) analyzed spelling errors committed by English Language specialists at Al-Balqa Applied University. The participants were [65] students. Data were collected by analyzing the participants' essays in "technical writing" course. She used Cook's classification of spelling errors. The results showed that the students committed four types of spelling errors, substitution errors, insertion errors, omission errors and transposition errors. Also, the results indicated that the difference between English and Arabic writing system is one of the major causes of such errors.

\section{Studies on foreign Learners}

Bancha,W.(2013) conducted a study on [31] first-year students at Prince Songka University majoring in International Business. Data were collected from students' writing sentences. The results showed ten types of spelling errors including: consonant substitution, vowel substitution, space inaccuracy,confusion in writing scripts, inaccurate double consonants, inflectional endings, letter reversals, vowel omissions and consonants omissions. The findings revealed that: the differences in writing system between English and Thai were not the major causes of such errors, the lack of adequate awareness of phonology and insufficient knowledge of inflectional morphology were the prime causes of their errors. Recommendations for remediation were suggested.

Esther, D.M (2015) did a study on [175] students and teachers taken fron [5] secondary schools in Akure South Local Government Area of Ondo State. Two instruments were used for data collection. Students' essay writing and a validated questionnaire. Data were analyzed using descriptive statistics of frequency counts and percentages. The results showed that spelling errors in students essays were omission of letters, addition of letters, and reduplication of letters among others. Some of the causes of errors were due to lack of revision after finishing writing and the shortage of books about spelling errors in school libraries. Recommendations were made based on the findings of the study.

\section{Methodology \& Procedures}

\section{Participants}

This study was conducted at Othman Bin Affan school for Basic Education/cycle2 in Umm AL-Quwain Educational Zone in the United Arab Emirates where English is taught as a foreign language from grade 1 .Thirty[30] learners (all males) from grade 6 (aged 12\&13 years old) participate in the study and the participants are taking seven of fifty minutes English classes per week. The book the learners use called 'Super Minds4' which follows British Spelling System.

\section{Data Collection and Analysis}

The participants have an oral spelling test which consists of (45) words. The words have been chosen from cook's spelling test with the help of the TDS (Teacher development specialist) at Othman School as they are frequently misspelt by Emirati learners. The words are read by their teacher to the participants four times and then at the end of the test the participants are given enough time to write the missing words. After conducting the test, the errors are classified into different types and scores of each type are statistically analyzed to get the percentages of each category. The percentages are analyzed to explore the common spelling errors made by the participants giving reasons behind committing them.

The Spelling test contains both one syllable words and multi-syllable ones; some of which correspond to their pronunciation and others do not,some have consonant clusters, some have double letters,some have regular plural forms and others have silent plural form letters. (See Appendix 1)

\section{Findings of the Study}

Classification of spelling errors is a crucial step to recognize spelling problems. (Williams, 1974 cited in Al-Harrasi, 2012). Accordingly, the spelling errors found in this study are categorized using Cook's classification (1999). 
Table1: shows the number of learners who commit the spelling errors under each category with examples.

\begin{tabular}{|c|c|c|c|c|}
\hline Type of Error & No. of Learners & Percentages & Target word & Misspelling \\
\hline Deletion/Omission & 20 & $66.66 \%$ & school & scool \\
\hline Substitution & 25 & $83.33 \%$ & $\begin{array}{c}\text { Family } \\
\text { Family } \\
\text { Ambition } \\
\text { pot }\end{array}$ & $\begin{array}{c}\text { Famely } \\
\text { Vamily } \\
\text { Ambision } \\
\text { bot }\end{array}$ \\
\hline Insertion/ addition & 16 & $56.33 \%$ & $\begin{array}{l}\text { Useful } \\
\text { modern }\end{array}$ & $\begin{array}{c}\text { Usefull } \\
\text { moderen }\end{array}$ \\
\hline Transposition & 10 & $33.33 \%$ & receive & recieve \\
\hline No errors & 2 & $6.66 \%$ & & \\
\hline
\end{tabular}

Twenty-fivelearners committed at least one error in their tests. It can be noticed from table(1) that most of the errors made by the participants are substitution type, nearly (83\%) of the learners made this type of error, e.g. (skool )forschool/ (reseive) for receive. The main cause of this type of error is the lack of knowledge of the relationship between sounds and written symbols and faulty pronunciation. Similarly, there is a large number of learners who made deletion or omission errors, e.g. (sin) for sign / (hokey) for hockey which constituted nearly $67 \%$ of the total errors that all the participants committed. On the other hand, the participants had relatively little with insertion /addition and transposition errors. (56\%) of the participants made insertion /addition errors such as (usefull) for useful moderen for

modernand nearly $34 \%$ of them made transposition errors, e.g. (bigen) for begin / (freind) for friend. /modren for modern

These results support what literature has indicated that substitution errors are the most common types of spelling errors Arabic learners make (Al-Zuoud\& Kalian, 2013), (AlHarrasi, 2012), (Al-Hassan, 2006) and (Al-Jabri, 2003).

\section{Discussion of the Findings}

Generally, most students in this study have spelling difficulty with one-syllable words whether with long or short vowels (e.g. bike/ wait/pot).Regarding to multi-syllable words the participants exhibit even more errors. Moreover,

the participants also make spelling errors with inflections, e.g.communicasion /acter.

The following shows an in-depth analysis of the four types of spelling errors with the sources of difficulty. Generally, the analysis of this study shows that the errors made by the participants can be attributed to incompatibility of pronunciation with the spelling in English. Frequently, learners spell as they pronounce ignoring all sorts of differences between spelling and pronunciation.Some errors are caused by the fact that many letters in English arewritten but not pro- nounced. In other words, these phonemes are deleted as they are not pronounced. For example, Wenesday for Wednesday / anser foranswer .It is also noticed that study shows that the participants mostly fail to differentiate between the vowel sound/e/ and / a/ ande.g.sandels or sendals for sandals and / a/ and /e/ and / e/ and /i/, e.g. pancel for pencil.

A possible explanation for such errors can be attributed to the lack of confusion between vowels in Arabic as there are only three distinct sounds that assimilate the English vowels, but they are diacritics put on the letters. Thus Arab learners of English are used to pronounce the vowels in reading or speech without having to write them. While in English there is no one-to-one correspondence between vowels and sounds most of the time, e.g. $\{\mathbf{a}\}$ can represent /a: / as in 'farm' or $/ \boldsymbol{x} /$ as in 'hat'.

This result is in agreement with (Al-Jarf, R, 2007), Kharma and Hajjaj 1989), (Swan and Smith, 1987) and other studies. Kharma and Hajjaj (1989) showed that because English is not a phonetic language, Arab learners struggle to master English spelling

Similarly, consonant substitution seems to be a big problem Emirati students. For example, the participants seem to confuse the uses of some letters and alternate between them, e.g.

1)-the consonant sound /s/ could be written as ' $z$ ' or ' $c$ '.

Buzy for busy/ prise for price.

for apricot.

2)- 'c' could be written such as ' $k$ '.e.g. aprikot

3)- ' $f$ ' could be written such as 'v'.e.g. sefen for

seven

4)- 'p' could be written such as 'b' e.g. sweeb for sweep

The main reason for such confusion is that two letters can be used to represent one sound and such case doesn't exist in Arabic writing system.

With regards to 'p' and 'v' Arabic doesn't have phonemes /p/ and $/ \mathrm{v} /$ so the participants tend to commit errors in using them by alternating their counterpart sounds/b/ and /f/ as they 
do not differentiate between them. This result is supported by Vaddapalli (2012) which shows that students mismatch /p/ and /b/.Zubeidi (1972, p.69) maintains that 'since most of English teachers are Arabs they themselves are unable to produce /p/ except through conscious effort.' If that is the case, the students are not supported by the perfect model from the beginning of learning. The correct pronunciation of such sound at a later stage becomes a work beyond the teachers' abilities.

Another type of errors the participants of this study commit is omission or deletion error. The participants tend to omit silent letter while writing, e.g.sin for sign/ nifefor knife/and nok for knock/ dotar for daughter/ In addition to that, the participants made some errors in doubling consonant letters, e.g'sucess' and' beginer'.Cook (1997) considers this error can be attributed to mother tongue interference. Although consonant doubling is in Arabic, but unlike English it is represented by letter with germination.

Concerning insertion, most of the insertion errors are in vowels. $57 \%$ of the participants insert vowels with consonant clusters, e.g. moderen for modern. Nearly all words in Arabic do not have consonant clusters, so it becomes a problem for our students to produce words of consonant clusters.(Aziz,1974). Therefore, to break the cluster, Arab learners try to insert a vowel such as in the above examples. Treiman (1991) says that difficulty with consonant cluster leads to misspelling.

In term of transposition $34 \%$ of the participants commit such error. They try to shift the positions of /e/ and/i/as in sceincefor science / freind for friend. The main cause of such error is resulted from the ignorance of spelling rules or their over-generalization. Transposition errors are not dangerous because they are unsystematic. They may occur because of the learners' inattention and carelessness. If the learners pay attention to such errors, they will not take place.

These findings also support what literature says that deficiency of spelling rules make learners have difficulty with the spelling of some words. (Al-Jaraf, 2007), and (Mahmoud, 2013).

\section{Pedagogical Implications and Sug- gestions for Teaching Spelling.}

Spelling should be taught like any other subject and teachers should adopt a suitable and flexible teaching method that is suitable for learners' age, ability and needs. (Schonell, 1985) cited in Al-Harrasi, 2012)

Several researches suggest some points that are useful for teaching and learning spelling. The following are some teaching suggestions adopted from Temple (1995), Cotterell,
(1974), Schonell, 1985), Wade (1974), and Pratelly (1988).

1. Long words can be broken into smaller parts or syllables to make it easier to learn and memorize, e.g. ve.ge ta .bles

2. Explain the spelling rules to the students along with their exceptions.

3. Use some mnemonics i.e. memory trick, e.g. a piece of pie.

4. Students can keep a list of new or difficult words and resort to them from time to time to keep them in the memory.

5. Drill and practice on spelling rules, such as prefixes and $\underline{y}$ to $\underline{\text { i.e. }}$.

6. Learners should expose themselves to receive more practice listening skill.

7. Learners should be encouraged to visualize words and syllables.

8. Using a dictionary will be useful for practicing the structure of words. Teachers can get use of dictionary to identify how a word is spelt.

9. Teach learners phonics and spelling in the English language to reduce the influence of Arabic spelling on English.

10. Develop spelling course consists of basics of spelling and integrated it in English courses, listening, reading, writing, speaking and vocabulary.

11. Encourage learners to read more. The more you read, the more you will see how different words spelt and used in context.

12. Tell learners to say and spell the words aloud.

13. Teach learners the commonly misspelled words such as (there, their, they`re, it`s, its, to, too, towtwo).

14. Teachers can make it a rule, to devote the first ten minutes every period to the dictation of the few new words learnt in the previous period.

15. Parents can take part in improving their children's spelling : ( Ta'ani, 2006 )

1. Encouraging them to look closely at words and talking to them about the words

2. Playing words games, with them such as:
a. Guess the word.
b. Find, erase and spell.
c. Building words.
d. Fill in puzzles.

3. Encouraging spare time reading:

a. Pointing out interesting newspaper items.

b. Encouraging visits to the library.

4. Use (look - think - cover - write - check) technique to overcome spelling errors.

16. Teacher should, especially in the early stages of an English course, be careful not to let spelling errors go uncorrected and so become deep - rooted and more difficult to overcome later on.

17. Memory Device:

This strategy passes through the following stages: 
1. Look at the word.

2. Copy the word.

3. Say the word.

4. Spell the word.

5. Write the word from memory.

6. Check the word.

7. Correct the errors.

18. Keep on alphabetical notebook in which learners can write and revise trouble some words.

19. Teachers should insist on teaching vowels and the ways of spelling them correctly and accurately.

20. Trace over a spelling with finger to pencil. This reinforces the visual memory task involved in spelling.

21. Highlight certain regularities and generalizations about English spelling and pronunciation; for example, the generalization that when (c) comes before (i), (e) or (y) it is pronounced /s/ and before (a), (o), and $(\mathrm{u})$ it is pronounced $/ \mathrm{k} / \mathrm{as}$ in:- city / cinema/ camel/ college/ cat/ camera/ center/.

22. When introducing the alphabet, especially at primary stage, show the learners that digraphs $(\mathrm{ch} / \mathrm{sh})$ represent one phoneme, because there is no single orthographic symbol in English to represent either of those phonemes.

23. Explain the differences in spelling between Arabic and English in order to avoid interference from the spelling system of the native language.

24. Encourage learners to read properly and accurately and do not turn a blind eye to any misread word. Thus, you will ensure that learners visualize the words and relate them to their written patterns. (El-Hibir and Altaha,1995,p.42)

25. With the availability of (IT) in our schools, a teacher can type out the students' written work without correcting it first and then let the students correct it by themselves with the help of computer, dictionaries...etc.

With these strategies, the researcher hopes that errors are bound to decrease.

\section{Recommendations for Further Stu- dies}

This study recommended conducting studies that help learners in minimizing spelling errors and help them in using suitable words.

* It is recommended to conduct a study on the relationship between spelling achievement and word frequency.

- A study on the relationship between spelling achievement and the length of the word is also highly recommended.

* It is recommended to conduct a study to investigate the effect of extensive reading on reducing spelling errors.

Finally, the research in this area needs to be continued since this study was conducted in schools where learners were representative of the government school, generalization is limited to schools with similar populations. Additional studies are recommended and needed to be conducted on private schools.

\section{Conclusion}

English spelling is more complex than an Arabic one. The English spelling and pronunciation system compared with the Arabic language is different for example, Arabic is written as it is pronounced, while many words in English have silent sounds, and words are multi-syllabic. Arab learners need more time and a lot of practice to master the most frequent words in the English language.

From the findings presented in this research, it can be concluded that the most common types of spelling errors made by Emirates grade six learners are substitution and omission. Addition or insertion and transposition type of errors are the smallest error types. These findings are in agreement with some studies (Al-Zuoud and Kabilan, 2013, Al-Harrasi, 2012, Khan 2012, Al-Jabri, 2006 and Al-Hassan, 2006).

Emirati Grade six learners seem to have little knowledge of spelling and some have not been taught how to visualize a word and make use of mnemonics of spelling rules. It is not suitable to teach spelling by only reading. Poor readers are not necessarily poor spellers and the contrary is possible.

Teachers should adopt a suitable approach to teach spelling effectively. Analyzing the types of spelling errors may help teachers a lot to choose the most suitable teaching method or approach.

\section{References}

[1].Al- Harrasi, K, “The Most Common Spelling Errors among OmaniLearners," Arab World English Journal, vol.3, No.2, 2012,pp. 96-116.

[2].Al- Hassan, S..An Alternative Approach to Teaching of Spelling in Grade5.Ins.Borg(Ed.), classroom Research in English Language Teaching in Oman. ,2006, pp.81-87, Muscat, Omani: oriental Press.

[3].Al- Jabri, F. Common English Spelling Difficulties of Omani Learners. Sultanate of Omani: ministry of Education, 2006.

[4].Al- Jarf, R,Faulty Strategies of EFL Freshman 
Spellers. 2007.

[5].Al- Jubouri, S.H, "Errors Analysis of Errors Committed by Iraqi EFLUniversity Learners in Adjectival Affixes," M.A.Thesis, Babylon University, College of Basic Education, 2006.

[6].Al- Othman, N, "Meeting the Challenges to Teaching the Spelling Systemof English: Voices from the Field in Kuwait," Journal of Educational and Psychological Sciences. Vol.4.No.3 December,2006,pp.6-33.

[7].Al-Oudat, A, "Spelling Errors in English Writing Committed by English -Major students at BAU," Journal of Literature, Languages and Linguistics.Vol.32, 2017, pp.43-47

[8].Al- Zuoud, K. and M.K. Kaliban, "Investigating Jordanian EFL Students'Spelling Errors at Tertiary Level," International Journal of Linguistics.vol.5, No.3, 2013, pp.164-176.

[9].Al-Hamash, Kh. And Abdul-Rahim, S.Teaching English as a foreignLanguage. Baghdad. Al-Liwan Press, 1979.

[10].Al-Jarf, R, "Sources of Spelling Errors in EFL Arab College Students," Retrieved-

fromhttp://repository.ksu.edu.sa/jspui/bitstream/123456 $789 / 7716 / 1 /$ listening _ spelling $\% 20$ strategies $\% 20$ in $\% 20$ EFL\%20 Arab \% college\%20 students, 2008, pd

[11].Brown, H.D, "Categories of Spelling Difficulty in Speakers of English as aFirst and Second Lan- ) guage," Journal of Verbal Learning and Verbal Behavior, Vol. 9,1970, pp. 232-236.

[12].Cook, V. (Teaching Spelling. Retrieved from http:// homepage.ntlworld.com/Vivian.c/ writings/papers/Teaching Spelling.htm,1999.

[13].Cotterell, G. A remedial Approach to a Spelling Disability. In Wade, B .and Wedell, K.ed Spelling: task and learner. Birmingham: Educational Review.,1974.

[14].Cronnell, B.A.Spelling English as a Second Language. In M.C.Murcia and L. McIntosh (Eds). Teaching English as a Second Language,Rowely, Mass: Newbury House, 1979b, pp.202-2014.

[15].El- Hibir, B. and F.M. Altaha, "Tips for Dealing with Spelling Errors," English Teaching Forum.

Vol.31, No.1, 1979b, pp. 41-42.

[16]. Esther, D.M, “ Spelling Errors: Causes, Influence on Students' Performance in English Language Essay Writing and Strategies for Correcting Them," Case Studies Journal ISSN(2305-509X)- Vol.4, No.8,
2015, pp. 66-70.

[17].Fitzgerald, J.A, "Spelling Words. Difficult for Children in GRADES II-IV,"Elementary School Journal. 53 December, 1952,pp. 221-228.

[18].Hassan, J. Assessment of Pupils Errors in English Spelling. M.A thesis, Baghdad University, College of Education/ Ibn-Rushid ,2000.

[19].Herman, W. Troubleshooting Basic Writing Skills. 14:Boston: Young, Jeffrey Inc.USA,1986.

[20].Kharma, N. and A. Hajjaj. Errors in English among Arabic Speakers: Analysis and Remedy. Harlow, UK: Longman, 1989.

[21].Naser, R.T .The Teaching of English to Arab Students. London: Longman,1963.

[22].Prattey, R.Spelling it out. London: BBC,1988. 23].Ramadan, S. M .A Study of Spelling Errors Made by third Preparatoryand Third Secondary Classes in Jordan Through Context Form. Unpublished M.A. Thesis, Yarmouk, Yarmouk University, 1986.

[24].Schonell, F. and P. Wise. Essentials in Teaching and Testing Spelling. Basingstoke: Macmillan, 1985.

[25].Smadi, O.M. A Study of Spelling Errors in Context.Al-Abhath.Vol.XLII,1994,pp.17-46.

[26].Swan, M .and B. Smith. Learner English. Cambridge: Cambridge University Press, 1987.

[27].Ta'ani, M. An Investigation of Spelling Errors Found in Written Compositions of the Second and Third Secondary Students in the U.A.E. Unpublished Ph.D.Thesis. University of Science and Technology,2006.

[28].Vaddapalli, M, "Spelling and Auditory Discrimination, Difficulties ofStudents in Oman: An Analysis ," Language in India, vol.12, No.1,2012, pp. 261276.

[29].Wade, B. Introduction: Spelling in Context. In Wade, B and Wedell, K.ed Spelling: task and learner. Birmingham: Educational Review, 1974.

[30].Williams, A. A Study of Spelling Error. In Wade, B .and Wedell, K.ed Spelling: task and learner. Birmingham: Educational Review, 1974. 
$\underline{\text { Appendix (1) }}$

\section{Oral Spelling Test}

\begin{tabular}{|l|l|l|l|}
\hline 1 & pencil & 24 & Friend \\
\hline 2 & pot & 25 & Knock \\
\hline 3 & bicycle & 26 & modern \\
\hline 4 & sign & 27 & dress \\
\hline 5 & receive & 28 & begin \\
\hline 6 & science & 29 & beginner \\
\hline 7 & scientist & 30 & believe \\
\hline 8 & communication & 31 & sandals \\
\hline 9 & knife & 32 & price \\
\hline 10 & telephone & 33 & sweep \\
\hline 11 & bike & 34 & write \\
\hline 12 & success & 35 & skip \\
\hline 13 & beautiful & 36 & walk \\
\hline 14 & seven & 37 & hour \\
\hline 15 & ambition & 38 & hockey \\
\hline 16 & useful & 39 & track \\
\hline 17 & people & 40 & computer \\
\hline 18 & successful & 41 & strawberry \\
\hline 19 & wait & 42 & apricot \\
\hline 20 & decide & 43 & lime \\
\hline 21 & family & actor \\
\hline 22 & daughter & business \\
\hline 23 & school & \\
\hline
\end{tabular}

